\title{
Collapsing health care in Serbia and Montenegro
}

\author{
Mary E Black
}

Mary E Black is a public health physician in London. Since the onset of war in the republics of former Yugoslavia she has consulted with the World Health Organisation, the United Nations High Commission for Refugees, and Physicians for Human Rights.

\begin{abstract}
Serbia and Montenegro together form the Federal Republic of Yugoslavia. As well as the Serb majority this includes the mixed province of Vojvodina, the mainly Albanian population in Kosovo, and the large Muslim minority in Sandzak. Since the start of war in 1991 the attention and sympathies of the world have focused on Bosnia and Croatia. The United Nations imposed economic sanctions on the federal republic in 1992, although in theory medical supplies and aid are exempt. The economy has now collapsed under the triple burden of war, loss of trade between the republics, and UN sanctions. A major public health catastrophe is unfolding in the federal republic.
\end{abstract}

I travel by road from Budapest to Belgrade as international air traffic has been halted by economic sanctions. The verge is littered with rubbish and toilet paper, souvenirs of the hundreds of thousands of travellers who have made an overland detour since fighting in Croatia and Bosnia severed the main road link from Europe to Greece and Turkey in 1991. The queue at the Hungarian-Serbian border is several hours long. As I approach Belgrade there are more queues: miles of cars in line for rationed petrol pushed in shifts by their owners or for a pittance by elderly people desperate to supplement their tiny pensions. The city is very clean: the air is country fresh and the river Sava is sparkling, untouched by pollutants as factory activity has largely ceased. State run food shops are virtually empty; there is hardly any milk this week, but the markets are full of farm produce brought in by country people.

Belgrade has fallen a long way from the heady prosperity of the 1970s, when Yugoslavs could afford to shop in Italy and holiday in Russia. The bloated and unstable economy, propped up by Western and Soviet loans, has collapsed owing to the cost of war, loss of trade between the warring republics, and the effect of the eonomic sanctions imposed by the United Nations. Gross national product has fallen in two years from $\$ 2600$ per person to $\$ 300$, leaving about four fifths of the population on or below the breadline. Families

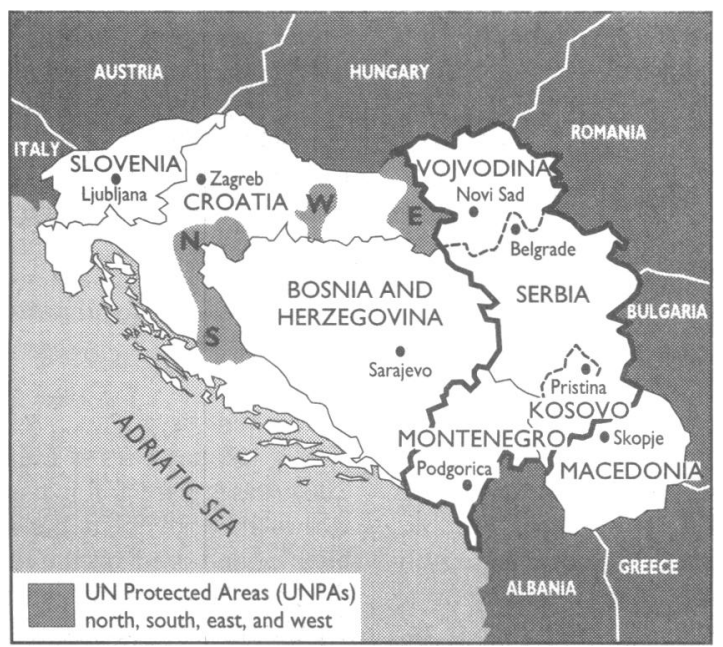

The republics of former Yugoslavia, fanuary 1993

\begin{tabular}{|c|}
\hline $\begin{array}{l}\text { Health services in the Federal } \\
\text { Republic of Yugoslavia } \\
\text { (Serbia and Montenegro) }\end{array}$ \\
\hline $\begin{array}{l}\text { Primary care-Group general practices, known as } \\
\text { domovi zdravlja, with attached specialist, pharmacy, } \\
\text { laboratory, and } x \text { ray facilities. Satellite surgeries known } \\
\text { as ambulantas. } \\
\text { Secondary care-Regional hospitals. } \\
\text { Tertiary care-University clinical centres and specialist } \\
\text { hospitals such as psychiatric hospitals, rehabilitation } \\
\text { centres. }\end{array}$ \\
\hline
\end{tabular}

live on dwindling savings and money from relatives abroad, the poorest scavenge in rubbish bins. The government has responded by printing money, and there is now hyperinflation at an unbelievable $1 \%$ per hour. Salaries and pensions, paid up to a month in arrears, are worth practically nothing when they finally arrive. Doctors and nurses take home DM30-40 a month. This buys less than one week's food for a family.

\section{Crisis in health care}

Before the war the health care system was a showpiece (see box). It delivered free comprehensive health care, spectacles, spa treatment, more doctors per person than Sweden, and more medications per person than Switzerland. Health care was funded by a contribution from salaries, which was paid into a central health fund. The government began tentative health care reforms in 1990, when the health fund was reduced by the weakening economy. ${ }^{1}$ Now the fund is empty, and health care is in crisis.

Dr Vuk Stambolovic is the medical coordinator of the Soros foundation, which supports reform and development of eastern European economies. "Prewar around $4 \%$ of gross national product was spent on health care. Now it is between 10 and $15 \%$, but that still means only around $\$ 34$ per person," he explains. "The health services are surviving on humanitarian aid, and the responsibility for health care is increasingly being put on to the international community." Officially, UN sanctions are blamed for everything that is wrong with health care in the Federal Republic of Yugoslavia, although many doctors will privately admit that all was not well before sanctions were imposed. Sanctions offer a propaganda opportunity for a government anxious for someone to blame for the catastrophe facing its people. In June of this year staff of the three main international agencies in Belgrade- the United Nations High Commission for Refugees (UNHCR), the World Health Organisation, and the International Federation of Red Cross and Red Crescent societies-made an unusual appeal to the heads of their agencies on the effects of sanctions. They cited a rapid increase in tuberculosis, the tripling of mortality in mental institutions in less than a year, a drop in immunisations, and deaths due to lack of fuel to transport patients to hospitals. Richard Garlock, acting chief of UNHCR Belgrade, adds, "Donations to 
the relief effort in former Yugoslavia are sometimes negatively earmarked for the Federal Republic of Yugoslavia, meaning we can't use the funds here." Nobody wants to give aid to Serbia, and when they do there are long bureaucratic delays in getting it in. ${ }^{34}$

Dr Hannu Vuori, WHO's special representative in Belgrade elaborates further. Before the war over $80 \%$ of pharmaceutical products and over $95 \%$ of all medical equipment were imported. Locally manufactured medical supplies were centrally organised, with each republic having almost total control over production of certain items and then selling them to the others. Loss of pan-Yugoslavian trade and distribution networks has therefore led to both excesses and absences of specific items in each republic. The UN sanctions specifically exempt medical supplies, ${ }^{5}$ but in practice the dinar is effectively worthless and the federal republic's ministry of health can no longer afford to pay in hard currency. In addition, the bureaucratic hurdle of getting approval from the sanction committee in New York adds months of delay and makes foreign companies unwilling to trade. Raw materials for what is left of the pharmaceutical industry are not exempt from the sanctions.

\section{Influx of refugees}

Many who can have left: young men unwilling to serve in the army, the intellectual élite, and many who have business or family contacts abroad have joined the growing lines at Belgrade's foreign embassies in search of exit visas. About 400000 have been successful. There has also been in influx of 750000 refugees from Croatia and Bosnia adding to the federal republic's total population of 10.5 million. At first glance they are barely visible: there are fewer people sleeping on the streets in Belgrade than in London. Over $95 \%$ are crammed into one or two roomed apartments with distant relatives or unrelated host families who are given minimal state support to care for them. Some are in flats vacated by people who have fled and the rest are in collective refugee centres. Refugees are entitled to free schooling and care in what is left of the health care system.

In the refugee section of Belgrade's children's hospital 12 mothers and their children live in the basement. One child is profoundly deaf, but his mother cannot afford the batteries to run his recently donated hearing aid. The ward above holds 25 inpatients with diarrhoea, asthma, and malnutrition. The staff nurse is visibly upset by conditions: "We do our best, but we have no disinfectant and only two bottles so we feed the children in shifts." We examine Maria, the youngest of four children of a poor family, who was admitted to hospital with marasmus, an increasingly common condition. Unicef has promised to deliver bottles and nappies to replace the currently used rags, but they have not yet arrived as they are in a convoy embroiled in a bureaucratic hold up at the border.

\section{Deteriorating hospitals}

$\mathrm{Mr}$ Stamatovic, the recently appointed director of Belgrade's university clinical centre, reels off a list of facts about this tertiary hospital complex in better times: 8000 employees, including 1220 doctors and 309 professors, and yearly figures of 350000 outpatients visits, 45000 operations performed, and about two million health interventions. He also reels off a diatribe against the international community. Yugoslavia was a founder member of WHO, but the federal republic is no longer a member after the World Health Assembly decided that it should not retain the seat belonging to the erstwhile Yugoslavia. In a political stand off the federal republic has refused to reapply under a new name,

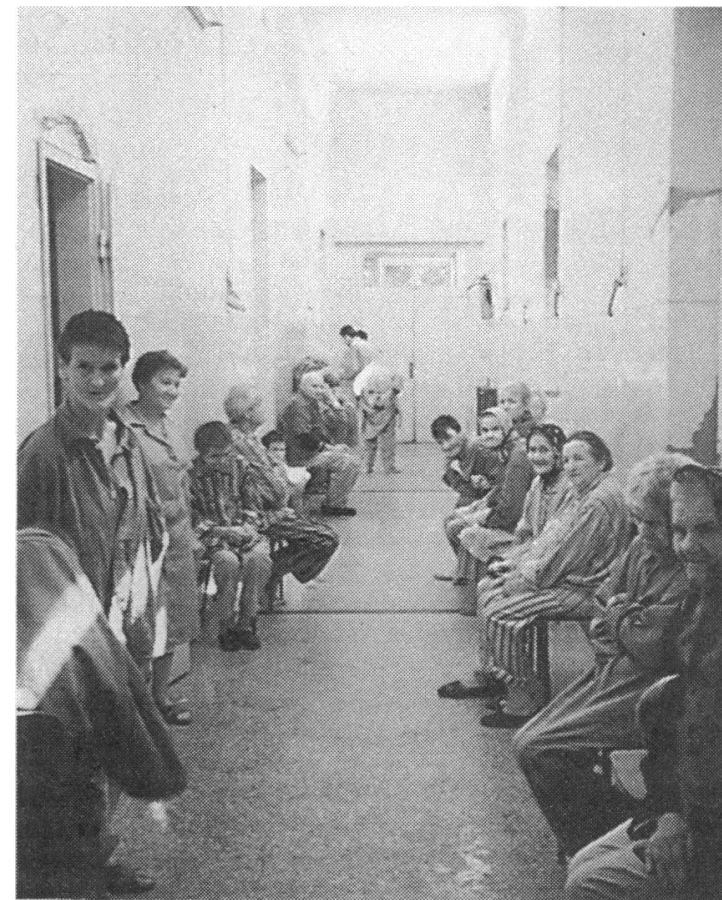

Psychogeriatric ward, Kovin hospital: no heating, drugs, bedclothes, or soap

and now local doctors interpret this with great bitterness as having been kicked out of WHO.

I last visited these hospitals when I worked with WHO a year ago. ${ }^{6}$ There has been a clear deterioration: surgical services are now in a catastrophic state, with supplies for only two to three days at a time and often the donated supplies are near their expiry date. Most elective surgery and nearly all plastic and reconstructive surgery has been cancelled. A shortage of artificial valves has denied surgery to some children with congenital cardiac defects. Dr Zivorad Dordević, director of the emergency surgical centre, said that they have tried to get fine sutures from Ethicon, their usual suppliers near Glasgow, but it has taken months to get the papers from the UN sanctions committee in New York. "We are rationed to 50 litres of intravenous fluid per day; previously we used up to 2000 . Only one anaesthetic machine is still working, and the wheelchairs are broken. Today the only antibiotic I have is penicillin. Soon all we will have left to work with is our hands. Then we will have to inform our government that we can no longer work any more."

At the infectious diseases clinic Dr Antonijevic shows me five cases of tetanus. Between 1980 and 1990 there were only 27 cases in Serbia. "We last had hepatitis B vaccine in March 1992. We don't have any second or third generation cephalosporins, and there is a huge increase in multiresistant bacteria due to the unregulated use of new antibiotics from the black market. Sometimes all I can offer patients is a kind word. I can't even fix the tap in the bathroom as I don't have a washer." The doctors resort to asking patients to buy their own drugs on the black market.

\section{Plight of mentally ill patients}

Deterioration clearly shows in services for the mentally ill. There are 4000 beds in five specialist residential psychiatric hospitals. One of these is at Kovin, $60 \mathrm{~km}$ east of Belgrade, where 44 doctors and 200 nurses care for just over 1000 patients, many of whom have been in the institution for years or have been abandoned by their families. As I come through the gate I see thin, barefoot patients dressed in ragged dirty clothes wandering around. There are Serbs, Muslims, and Croats and many don't even know that 
there is a war. About 120 are refugees from Bosnia and Croatia, many were found abandoned in the war zones. Dr Dusan Jagodić has been the director for 15 years. The past two have been disastrous, and his budget has fallen by $90 \%$. He previously received DM 35 a day for each patient: now it is DM4, but paid one month late by which time it is worth almost nothing. "We can't practise psychiatry. Winter is coming and we can't even heat the hospital. We have no fuel to cook or hot water to wash patients and their clothes. Mentally ill patients destroy their shoes, sheets, and clothes. Now some don't even have pyjamas. We feed them beans, cabbage, and pasta; we can manage $650 \mathrm{~g}$ of bread a day. I can't even keep records any more; how can I spend money on a note book when my patients need bread?" In 1991, 170 patients died but 136 have died already in the first six months of 1993. Two years ago they had two or three new cases of tuberculosis a year, this year they have had 25 . Checking a sample of 27 ward records shows that over the past two months the already underweight patients had lost an average of $1.9 \mathrm{~kg}$. Pharmacy records show that the hospital supplies are a tenth of what they were before the war. Half now come from international aid and half from orthodox church groups.

\section{Custodians, not doctors}

The wards are tidy but smell strongly of urine as there is no soap, detergent, or disinfectants. There is also a smell of petrol, used to treat head lice, and the women have shaved heads. There are no sanitary towels or even cotton wool so women patients with periods have no protection. Drugs are carefully reserved for the most aggressive and disturbed, but the number of injuries has risen. Staff reported that earlier this year a staff member lost three teeth, a patient had his arm broken, one had his ear ripped off, one was castrated, and another was disembowelled. All the pictures have been broken by disturbed patients. None of these problems appear to be related to low staffing levels. Staff mingle with patients and staff-patient relations seem better to me than in many psychiatric hospitals in western Europe and the United States. There is a sense that they are all in this mess together. Visitors are rare, and we are surrounded by patients pleading for cigarettes, which the hospital is no longer able to give them. In one ward a woman is tied to a bedstead. Dr Dobrivoj Olcan says, "We can't do any therapy, patients can't concentrate. Now we have to use tie up and restrain therapy." A young Australian male patient tells me, "This is not a hospital, here even a mentally healthy person would go mad." Dr Bojana Simic sits with her patients in the psychogeriatric ward. It is one of the saddest sights I have seen this year. Patients lie huddled on urine soaked mattresses in ragged dirty pyjamas. They have no blankets. "We try our best, but now we are custodians not doctors," she says.

\section{Montenegro}

Before the war Yugoslavia was an inexpensive holiday destination for millions of Europeans including me. I revisit Budva, a resort on the coast of Montenegro, the second republic in the Federal Republic of Yugoslvia. Last year Montenegro kept its borders open and was rewarded with the highest percentage of refugees of any of the Yugoslavian republics. ${ }^{7}$ The mediaeval walled city of Budva was levelled by an earthquake in 1979. Donations from all the Yugoslavian republics enabled an authentic reconstruction, this time with modern sewers and electricity. The town is still bustling, but this time I am the only foreigner here. Few people are shopping except for the nouveau riche-paunchy men with open shirts, heavy gold medallions, and Mercedes who have made fortunes dealing in food, clothes, arms, fuel, and pharmaceutical goods and to whom UN sanctions are the business opportunity of the decade. Deutschmarks are traded openly on the street. While I am there the billion dinar note is issued, although in reality several zeros have been knocked off already.

Just outside the town is the 10 year old showpiece clinic or dom zdravlja, which has 30 doctors and 30 nurses to serve a population of 20000 and tourists. Dr Goran Pesovic examines a child with an ear infection and tells me the usual story. Although well staffed, they have only basic drugs so the child's mother will probably pay for drugs in one of three new private pharmacies in the town where the shelves are full of Italian, Slovenian, and Macedonian products. Sunshine makes everything look better. I am reminded of an indignant member of the audience at a talk I gave in London last year who described the arrival in England of Croatian refugees. "But they didn't look like refugees," he spluttered. "They were suntanned. We were conned." Refugees will return to Budva's hotels this winter: they were moved inland to make way for tourists this summer. They have no money for black market drugs and must make do with what the government and Red Cross pharmacies can provide. On my way to the airport at 5 am hopeful queues for milk have already formed.

\section{Conclusion}

I leave Belgrade's deserted international airport on a UN flight to Zagreb, which whisks me over the front lines and the border queues. During this visit in August and September 1993, I have been able to wander around and speak to whomever I wished. It was not difficult to separate facts from propaganda, but in fact there is little need for propaganda as the health care situation is so desperate. The economic effects of UN sanctions are clearly damaging the health of the population, affecting the poorest and most vulnerable groups most of all. Although not intended to do so, sanctions are contributing to the collapse of health services and are hampering humanitarian aid efforts. I am left with unanswered questions. How long can doctors and nurses continue to work for money that won't even feed their families? Why do politicians persist in telling us that economic sanctions are a bloodless alternative to war? Why do those who cause and contribute to wars not count the costs in human misery before they start? I leave behind a country and a health service moving inexorably backwards.

I thank Dr Hannu Vuori and the staff of WHO in Belgrade for their assistance and many local colleagues who helped with background information.

1 Tosic O. Serbia: Disintegration of health care system. Lancet 1992;340:295-6.

2 Kamm H. Serbia's health catstrophe. UN Sanctions on "pariah" medicines. International Herald Tribune 1993:23 August:4.

3 Dillner L. Agencies warn of winter disaster in former Yugoslavia. BMF 1993;307:887.

4 Wareing R, Faber D, Robathan A, Foster D. Report into the provision of health care and the availability of medicines, equipment and medical supplies in the Federal Republic of Yugoslavia and the Bosnian-Serb republic since the imposition of diplomatic and economic sanctions. Report by an all-party delegation of members of parliament visiting Yugoslavia. London: HMSO, 1993.

5 United Nations Security Council. Resolutions 757 and 820. New York: UNSC, 1992.

6 Redmond T. Mission report to the Federal Republic of Yugoslavia. Geneva: World Health Organisation, 1992.

7 Black ME. Europe's poor response to refugees from former Yugoslavia. BMf 1993;306:1481.

(Accepted 19 October 1993) 